\title{
Corrigendum
}

\section{The Treatment of Regulatory Convergence in Preferential Trade Agreements}

\author{
RODRIGO POLANCO LAZO AND PIERRE SAUVÉ
}

doi:10.1017/S1474745617000519, published by Cambridge University Press, 28 December 2017.

The above article was published with an error in the first author's affiliation. The correct affiliation is 'World Trade Institute, University of Bern and University of Luzern, Switzerland'.

The author apologizes for this error.

\section{Reference}

Polanco Lazo, R. and P. Sauvé (2017), 'The Treatment of Regulatory Convergence in Preferential Trade Agreements', World Trade Review, 1-33. 